\title{
SEBARAN UKURAN PANJANG DAN NISBAH KELAMIN IKAN MADIDIHANG (Thunnus albacares) DI SAMUDERA HINDIA BAGIAN TIMUR
}

\section{LENGTH DISTRIBUTION AND SEX RATIO OF YELLOWFIN TUNA (Thunnus albacares) IN THE EASTERN INDIAN OCEAN}

\author{
Arief Wujdi, Bram Setyadji dan Budi Nugraha \\ Loka Penelitian Perikanan Tuna \\ Teregistrasi I tanggal: 20 Agustus 2014; Diterima setelah perbaikan tanggal: 26 November 2015; \\ Disetujui terbit tanggal: 01 Desember 2015 \\ e-mail:arief_wujdi@yahoo.com
}

\begin{abstract}
ABSTRAK
Ikan madidihang atau tuna sirip kuning (Thunnus albacares) merupakan salah satu komoditas penting bagi industri perikanan di Indonesia dengan hasil tangkapan tertinggi dibandingkan jenis tuna lainnya. Sebagai dasar pengelolaan sumberdaya ikan yang berkelanjutan, diperlukan data dan informasi tentang komposisi ukuran layak tangkap yaitu membandingkan proporsi rata-rata ikan tertangkap (Lc) dan matang gonad (Lm), serta nisbah kelamin sebagai indikator pendugaan kemampuan memijah. Pengumpulan data dilakukan melalui program observasi diatas kapal rawai tuna yang berbasis di Benoa, Pelabuhanratu dan Bungus dari bulan Agustus 2005 hingga November 2013. Penghitungan nisbah kelamin menggunakan uji Chi-Square $\left(\mathrm{X}^{2}\right)$ dengan tingkat kepercayaan $95 \%$. Hasil penelitian menunjukkan bahwa distribusi ukuran panjang cagak ikan madidihang berkisar antara 30-179 cm, modus ukuran $106-110 \mathrm{~cm}$ dan rata-rata $101,65 \mathrm{~cm}$. Sebanyak 81,03\% madidihang yang tertangkap berukuran lebih besar daripada Lm yang berarti telah layak tangkap. Nisbah kelamin betina:jantan adalah 1:1,45 mengindikasikan dominansi ikan jantan. Hubungan antara nisbah kelamin dengan panjang ikan menunjukkan signifikansi dimana ikan betina semakin berkurang pada ukuran $120-180 \mathrm{~cm}$, serta tidak ditemukan lagi pada ukuran lebih dari $170 \mathrm{~cm}$. Korelasi nisbah kelamin dan panjang cagak dapat dideskripsikan dengan persamaan regresi sebagai berikut: 1,8013 - 0,0099 FL dengan nilai $\mathrm{R}^{2}=0,8058$.
\end{abstract}

KATA KUNCI: Ikan madidihang, sebaran panjang, nisbah kelamin, Samudera Hindia bagian timur

\section{ABSTRACT}

Yellowfin tuna or YFT (Thunnus albacares) is one of the important commodity for the fishing industry in Indonesia because it has the highest catches compared with other tunas. In order to fisheries resources management, it was necessary to monitor the size composition compared between proportion average size captured $(\mathrm{Lc})$ and maturity size $(\mathrm{Lm})$ to meets the size eligibility, as well as the sex ratio as an indicator to estimate the ability of spawn. Data collected by scientific observers program which was following tuna longline operation mainly based in Benoa, Palabuhanratu and Bungus Fishing Port, from August 2005 to November 2013. Chi-Square analysis with $95 \%$ confidence level also implemented to determine sex ratio between female and male. The result indicated that YFT were caught has size ranged between $30-179 \mathrm{~cm}$, size mode ranged between 106-110 cm and the mean was 101,65 cm. Mostly YFT (81,03\%) was greater than its maturity size (Lm) and that's mean have been worthy to be captured. Sex ratio of $(F: M) 1: 1,45$ was observed which indicates male was dominant. Correlation between sex ratio and length proved to be significant where the female was diminishing in size between 120-180 cm, even female was no longer found in size more than $170 \mathrm{~cm}$. Correlation between sex ratio and length can described as a regression equation $=1,8013-0,0099 \mathrm{FL} ; R^{2}=0,8058$.

KEYWORDS: Yellowfin tuna, size distribution, sex ratio, eastern Indian Ocean

\section{PENDAHULUAN}

Ikan madidihang atau tuna sirip kuning (Thunnus albacares) merupakan jenis komoditas tuna yang memiliki hasil tangkapan tertinggi dibandingkan dengan jenis tuna lainnya di Indonesia. Hasil tangkapan keempat jenis tuna di Indonesia secara keseluruhan pada tahun 2004 hingga 2011 mencapai 1.297 .062 ton, dimana persentase hasil tangkapan ikan madidihang mendominasi hingga 69\% dari total hasil tangkapan. Selanjutnya hasil tangkapan diikuti oleh tuna mata besar (Thunnus obesus) 24\%, tuna albakora (Thunnus alalunga) 6\% dan hasil tangkapan tuna sirip biru selatan (Thunnus maccoyii) memiliki persentase kurang dari 1\% (Anonimus, 2012).

Ikan madidihang merupakan spesies yang bermigrasi jauh (highly migratory species) yang distribusinya berada di perairan tropis dan subtropis dan melimpah pada kolom permukaan dengan kisaran suhu $15-31^{\circ} \mathrm{C}$ (Collette \& Nauen, 1983). Spesies ini dapat ditemukan di Samudera 
Atlantik, Hindia dan Pasifik, namun tidak ditemukan di Laut Mediterania (Anonimus, 1994). Sedangkan penyebaran ikan madidihang di Indonesia meliputi perairan Samudera Hindia (barat Sumatera hingga selatan Jawa, Bali dan Nusa Tenggara), Selat Makasar, Laut Flores, Teluk Tomini, Laut Sulawesi, Laut Arafura, Laut Banda, perairan sekitar Maluku dan Samudera Pasifik (Uktolseja et al., 1991; Wudianto \& Nikijuluw, 2004).

Kondisi stok ikan madidihang di Samudera Hindia dalam keadaan baik (Anonimus, 2013a,b). Meskipun demikian, tingginya permintaan di pasar dunia dalam beberapa tahun terakhir berdampak terhadap pemanfaatan yang makin internsif. Menurut Anonimus (2013a), laju tangkap ikan madidihang yang tertangkap oleh armada pukat cincin menunjukkan trend peningkatan, sedangkan disisi lain laju tangkap armada rawai tuna cenderung stabil. Upaya yang dapat dilakukan dalam rangka mewujudkan pengelolaan sumberdaya ikan tuna yang rasional dan berkelanjutan adalah dengan memperhatikan aspek biologinya (Andamari et al., 2012). Salah satunya dengan pemantauan komposisi ukuran yang layak tangkap. Penelitian ini bertujuan untuk mengetahui distribusi ukuran dan nisbah jenis kelamin ikan madidihang yang tertangkap oleh armada rawai tuna di Samudera Hindia bagian timur. Informasi ini dapat digunakan sebagai pintu masuk (entry point) pendugaan status pemanfaatan ikan madidihang dikaitkan dengan kesempatan melakukan regenerasi (pemijahan) untuk menjaga kelestariannya di alam.

\section{BAHANDANMETODE Pengumpulan Data}

Pengumpulan data penelitian diperoleh melalui program on-board scientific observer, yaitu kegiatan validasi terhadap teknik dan operasional kegiatan penangkapan ikan secara langsung dengan mengikuti kapal rawai tuna komersil yang beroperasi di Samudera Hindia bagian timur yang tersebar pada posisi geografis 0-34 ${ }^{\circ} \mathrm{LS}$ dan $76-129^{\circ} \mathrm{BT}$. Data dikumpulkan pada bulan Agustus 2005 sampai November 2013 dengan mengikuti kapal rawai tuna komersil yang berbasis di Pelabuhan Benoa, Pelabuhan Perikanan Nusantara (PPN) Palabuhanratu, dan Pelabuhan Perikanan Samudera (PPS) Bungus.

Kapal rawai tuna yang berbasis di Benoa beroperasi di selatan Jawa hingga Nusa Tenggara, kapal yang berbasis di PPN Palabuhanratu beroperasi di barat daya Selat Sunda, dan kapal yang berbasis di PPS Bungus beroperasi di barat Kepulauan Mentawai (Gambar 1). Data yang dikumpulkan meliputi posisi pemasangan alat tangkap (setting), komposisi jenis hasil tangkapan, ukuran panjang cagak (fork length) dengan ketelitian 1 centimeter, dan jenis kelamin yang diamati berdasarkan pengamatan visual dengan cara pembedahan diatas kapal.

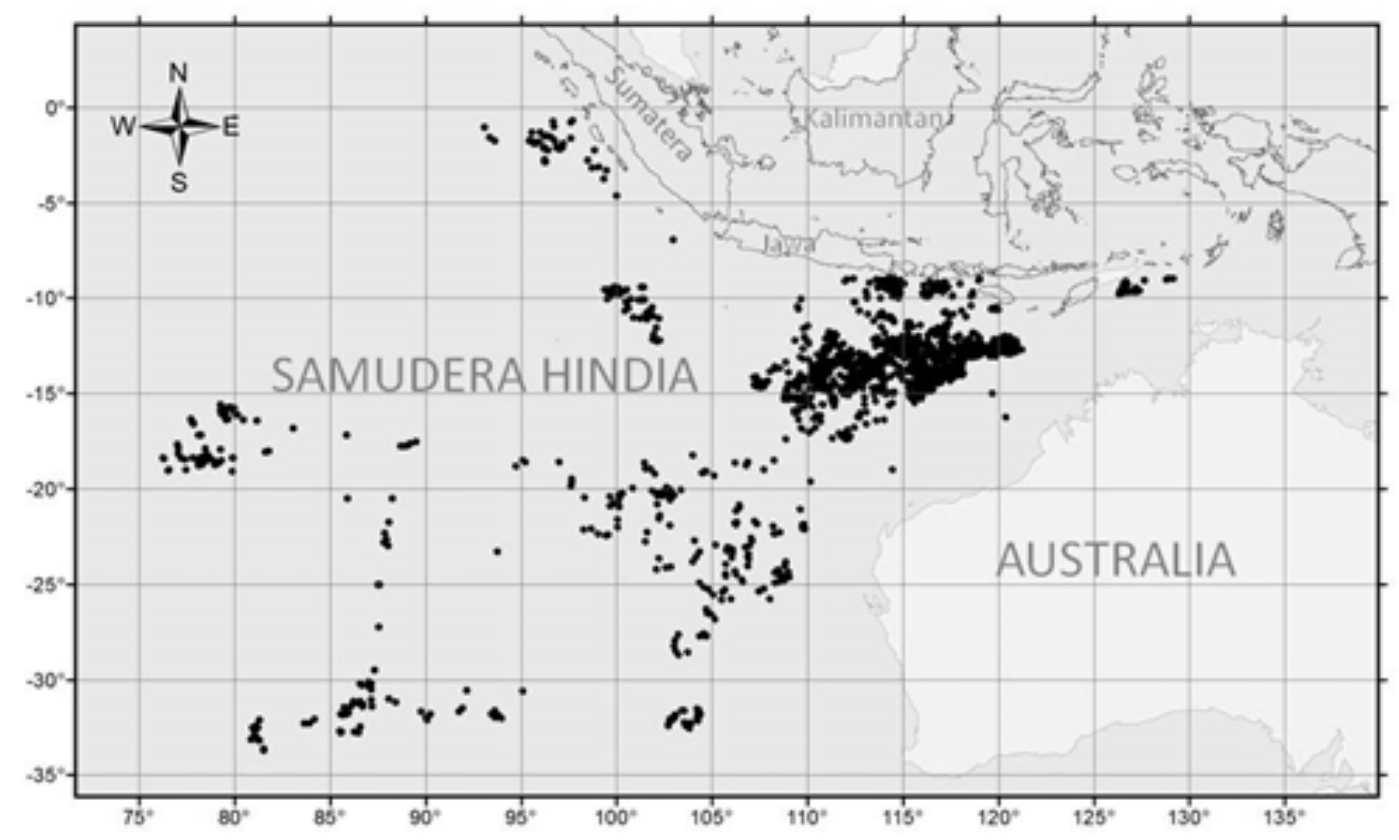

Gambar 1. Peta daerah penelitian periode 2005-2013 di Samudera Hindia bagian timur Figure 1. Map of research area from 2005 to 2013 in the eastern Indian Ocean Keterangan/Remarks: bulatan hitam menunjukkan lokasi penangkapan rawai tuna/the black dots showed as fishing ground of tuna longliner 


\section{Analisis Data}

Data ukuran panjang cagak, jenis kelamin dan posisi pemasangan alat tangkap hasil pengamatan ditabulasi dengan software Microsoft Excel, kemudian ditampilkan dalam bentuk peta tematik berdasarkan koordinat dengan ukuran grid $5 \times 5^{\circ}$ lintang dan bujur menggunakan aplikasi ArcGIS versi 10.1. Ukuran panjang cagak ikan yang diamati kemudian dibandingkan dengan panjang rata-rata matang gonad $\left(\mathrm{L}_{\mathrm{m}}\right)$ yaitu $100 \mathrm{~cm}$ (Anonimus, 2013a) untuk memperoleh komposisi ikan madidihang yang layak tangkap.

Nisbah kelamin ikan madidihang betina dan jantan ditabulasi dan dihitung dengan menggunakan uji chisquare $\left(\mathrm{X}^{2}\right)$. Hipotesis $\left(\mathrm{H}_{0}\right)$ dalam studi ini adalah nisbah kelamin betina dan jantan dalam kondisi seimbang (1:1) pada tingkat kepercayaan $95 \%$. Analisis chi-square menggunakan rumus sebagai berikut (Hedianto \& Purnamaningtyas, 2013):

$X^{2}=\frac{\sum\left(O_{i}-e_{i}\right)^{2}}{e_{i}}$

dimana:

$\mathrm{X}^{2}=$ nilai chi-square
$\mathrm{O}_{\mathrm{i}}=$ frekuensi ikan jantan/betina hasil observasi

$\mathrm{e}_{\mathrm{i}}=$ frekuensi yang diharapkan

\section{HASIL DAN BAHASAN \\ Hasil}

\section{Sebaran Ukuran Panjang Cagak}

Pencatatan data ikan madidihang yang tertangkap rawai tuna di Samudera Hindia pada tahun 2005-2013 sebanyak 2.254 ekor, dan diantaranya dapat diukur panjang cagaknya sejumlah 2.230 ekor. Ikan tersebut memiliki panjang cagak berkisar antara $30-179 \mathrm{~cm}$ dengan rata-rata $101,65 \mathrm{~cm}$ dan modus pada kelas panjang cagak antara 106-110 cm (Tabel 1 dan Gambar 2). Apabila dibandingkan dengan panjang rata-rata matang goand $\left(\mathrm{L}_{\mathrm{m}}\right)$ menurut Anonimus (2013a) adalah $100 \mathrm{~cm}$, maka sebanyak $81,03 \%$ madidihang telah layak tangkap yang tersebar merata di Samudera Hindia, sedangkan 423 ekor $(18,97 \%)$ belum layak tangkap yang banyak tertangkap di Samudera Hindia bagian barat Bengkulu (posisi geografis antara 3$8^{\circ} \mathrm{LS}$ dan $95-100^{\circ} \mathrm{BT}$ ) dan di tengah wilayah Samudera Hindia bagian timur, yaitu pada posisi geografis antara $18-23^{\circ} \mathrm{LS}$ dan $100-105^{\circ} \mathrm{BT}$ (Gambar 3).

Tabel 1. Jumlah spesimen, rerata dan variasi sebaran panjang ikan madidihang

Table 1. Number of sample, mean, and variance of yellowfin length distribution

\begin{tabular}{ccccccc}
\hline \multirow{2}{*}{$\begin{array}{c}\text { Tahun/ } \\
\text { Year }\end{array}$} & \multirow{2}{*}{} & \multicolumn{5}{c}{ Panjang/Length $(\mathbf{c m F L})$} \\
\cline { 3 - 7 } & 12 & Min & Mean & Max & sd & SE \\
\hline 2005 & 59 & 54 & 111,8 & 148 & 30,6 & 8,8 \\
2006 & 208 & 53 & 122,5 & 162 & 21,6 & 0,9 \\
2008 & 448 & 45 & 131,9 & 161 & 18,3 & 1,3 \\
2009 & 333 & 56 & 143,8 & 178 & 28,4 & 1,3 \\
2010 & 184 & 30 & 131,9 & 178 & 27,4 & 1,5 \\
2011 & 64 & 45 & 123,3 & 160 & 28,4 & 2,1 \\
2012 & 197 & 61 & 104,4 & 179 & 21,5 & 2,8 \\
2013 & 205 & 30 & 116,5 & 172 & 26,8 & 1,5 \\
\hline Total & $\mathbf{2 . 2 3 0}$ & $\mathbf{3 0}$ & $\mathbf{1 0 1 , 6}$ & $\mathbf{1 7 9}$ & $\mathbf{2 7 , 4}$ & $\mathbf{0 , 6}$ \\
\hline
\end{tabular}

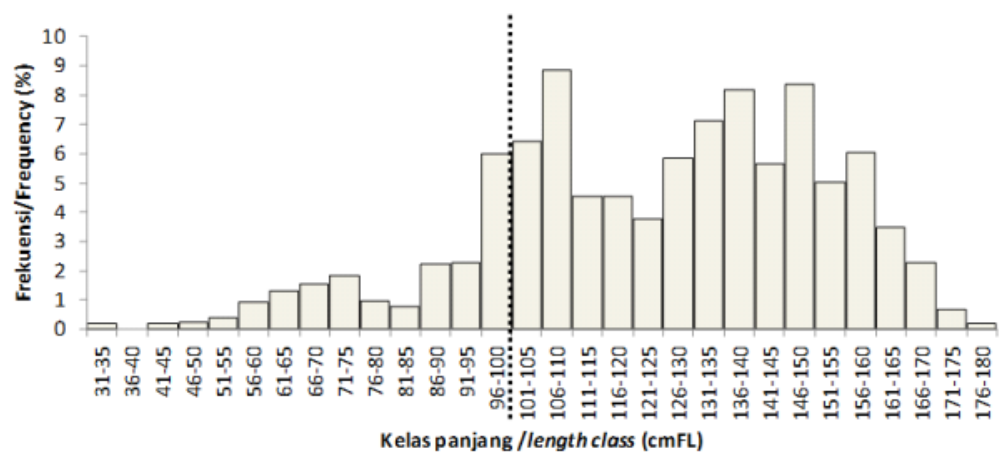

Gambar 2. Sebaran panjang ikan madidihang yang tertangkap di Samudera Hindia bagian timur.

Figure 2. Length distribution of yellowfin tuna caught in the eastern Indian Ocean.

Keterangan/Remarks: Garis putus-putus menunjukkan ukuran pertama matang gonad $100 \mathrm{~cm} /$ the dash line showed as size at first maturity $100 \mathrm{~cm}$ (Anonimus, 2013a) 


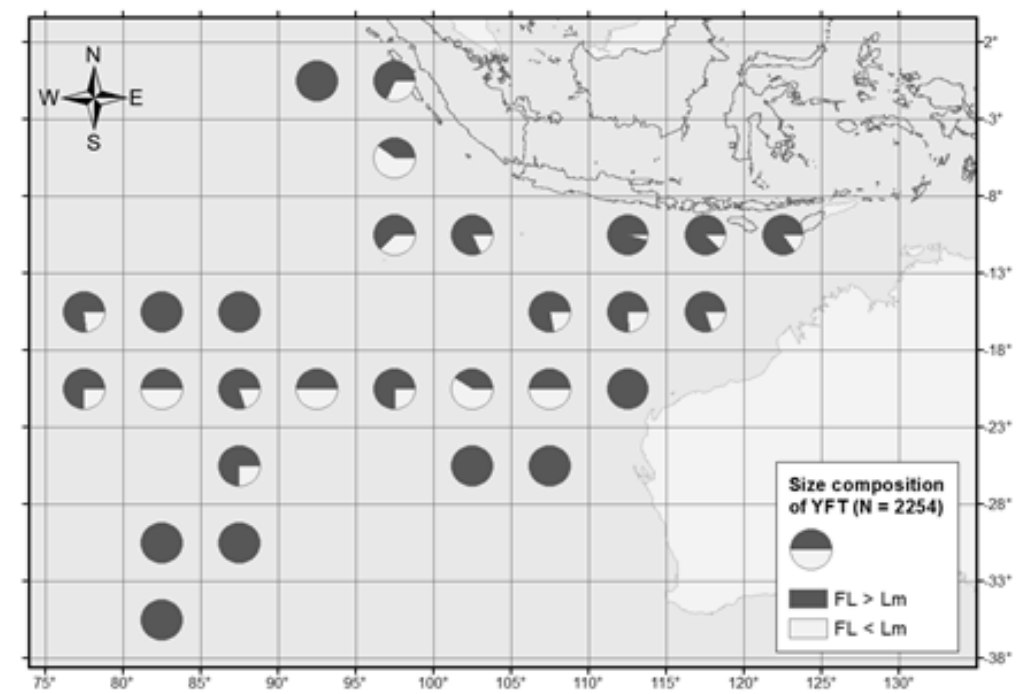

Gambar 3. Sebaran spasial panjang cagak ikan madidihang dibandingkan dengan panjang pertama kali matang gonad di Samudera Hindia bagian timur

Figure 3. Spatially-size distribution of yellowfin tuna compared its length at first maturity in Eastern Indian Ocean

\section{Nisbah Kelamin}

Berdasarkan hasil pengamatan bahwa tidak semua ikan madidihang yang tertangkap rawai tuna dapat diidentifikasi perbedaan jenis kelaminnya. Madidihang berjenis kelamin jantan sebanyak 932 ekor $(41,79 \%)$; betina 645 ekor $(28,92 \%)$; dan 653 ekor $(29,28 \%)$ tidak diketahui jenis kelaminnya (unknown). Ikan madidihang betina berukuran antara 30-170 cm sedangkan ukuran pejantan berkisar 43 $178 \mathrm{~cm}$. Apabila dibandingkan dengan panjang rata-rata matang gonad $\left(\mathrm{L}_{\mathrm{m}}\right)$ madidihang di Samudera Hindia menurut Anonimus (2013a) adalah $100 \mathrm{~cm}$, maka sebanyak $94,11 \%$ betina dan $93,47 \%$ jantan memiliki ukuran yang lebih besar daripada $\mathrm{L}_{\mathrm{m}}$. Secara keseluruhan 93,73\% ikan madidihang yang tertangkap dengan rawai tuna diindikasikan sudah matang gonad.

Perbandingan nisbah kelamin betina dan jantan adalah $1: 1,45$. Berdasarkan hasil uji chi-square pada taraf kepercayaan $95 \%$ menunjukkan adanya perbedaan yang nyata dimana nilai $\mathrm{x}^{2}{ }_{\text {hitung }}(52,89)$ lebih besar daripada $\mathrm{x}_{\text {tabel }}^{2}$ $(3,84 ; a ́=0,05 ; d b=1)$. Secara statistik, nisbah kelamin betina dan jantan pada ukuran 86-105 cm dan 121-150 cm berada pada kondisi seimbang (1:1). Nisbah kelamin jantan lebih dominan daripada betina pada ukuran $106-110 \mathrm{~cm}$, 116-120 cm dan ukuran lebih dari $150 \mathrm{~cm}$ (Gambar 4).

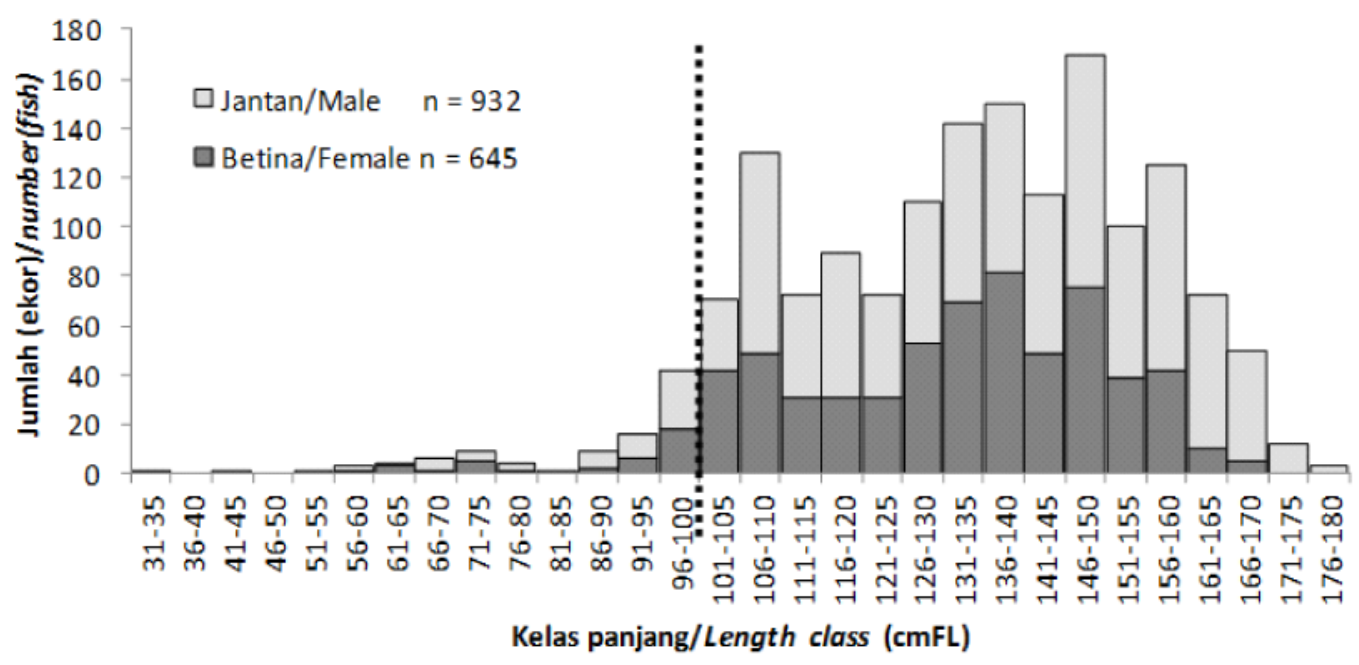

Gambar 4. Nisbah jenis kelamin ikan madidihang berdasarkan kelas panjang

Figure 4. Sex ratio of YFT according to length class

Keterangan/Remarks: Garis putus-putus menunjukkan ukuran pertama matang gonad $\left(\mathrm{L}_{\mathrm{m}}\right) 100 \mathrm{~cm} /$ the dash line showed as size at first maturity $\left(\mathrm{L}_{\mathrm{m}}\right) 100 \mathrm{~cm}$ (Anonimus, 2013a) 
Nilai nisbah kelamin berfluktuasi seiring dengan bertambahnya ukuran panjang dengan pola yang tidak beraturan pada ukuran kurang dari $120 \mathrm{~cm}$, namun cenderung memiliki pola tertentu pada ukuran lebih dari $120 \mathrm{~cm}$. Nisbah kelamin mengalami penurunan pada selang ukuran $120-180 \mathrm{~cm}$. Hal ini berarti ikan betina akan semakin berkurang seiring bertambahnya ukuran. Penurunan nisbah kelamin membentuk persamaan regresi, yaitu nisbah kelamin $=1,8013-0,0099$ FL dengan koefisien determinasi $\left(\mathrm{R}^{2}\right)$ sebesar 0,8058 . Ikan betina tidak lagi ditemukan pada ukuran yang lebih besar, khususnya pada ukuran panjang lebih dari $170 \mathrm{~cm}$ (Gambar 5).
Ikan madidihang berukuran lebih dari $100 \mathrm{~cm}$ yang tertangkap di Samudera Hindia sekitar Indonesia (posisi geografis antara $2^{\circ} \mathrm{LU}-13^{\circ} \mathrm{LS}$ dan $90-125^{\circ} \mathrm{BT}$ ) didominasi oleh kelamin jantan $(51,88 \%)$ dibandingkan betina $(29,26 \%)$. Perbandingan jumlah ikan jantan dan betina yang tertangkap oleh armada rawai tuna Indonesia mengalami penurunan terutama yang tertangkap diluar Zona Ekonomi Ekslusif Indonesia yaitu pada posisi geografis antara $13-38^{\circ} \mathrm{LS}$ dan $75-120^{\circ}$ BT. Jumlah ikan madidihang jantan yang tertangkap pada wilayah tersebut memiliki prosentase $31,40 \%$ dibandingkan ikan betina, yaitu $27,81 \%$ (Gambar 6).

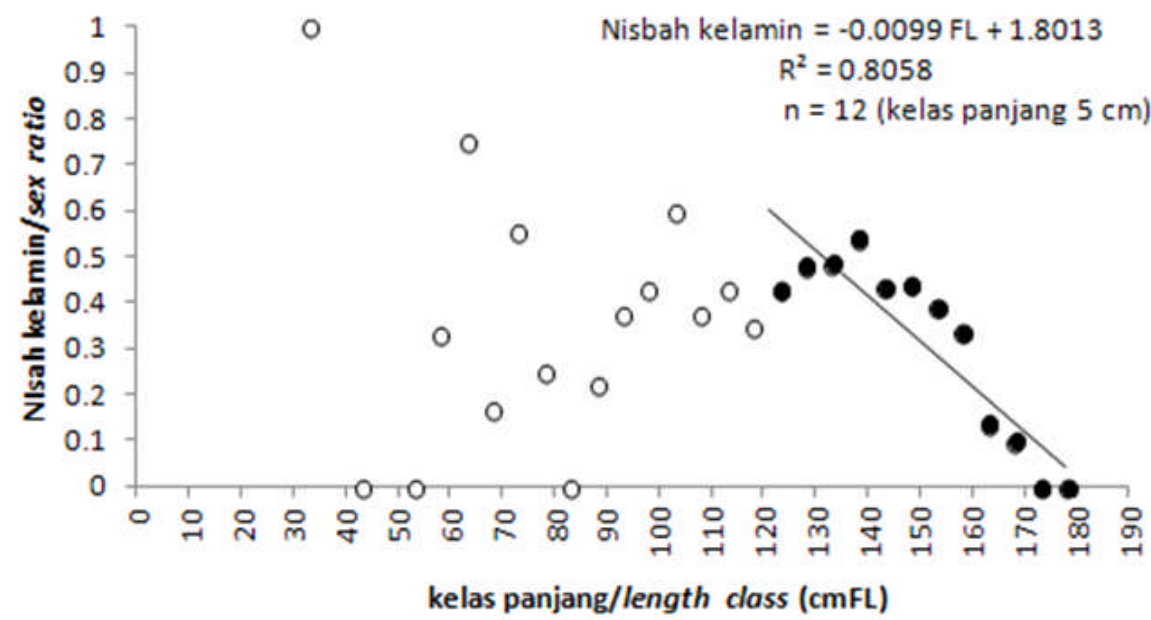

Gambar 5. Hubungan antara nisbah kelamin betina dan panjang cagak ikan madidihang yang tertangkap rawai tuna di Samudera Hindia Bagian Timur.

Figure 5. Relationship between female proportion and fork length of yellowfin tuna caught by tuna longline in Eastern Indian Ocean.

Keterangan/Remarks: bulatan hitam menunjukkan batasan selang kelas 120d"FLd"180 yang digunakan dalam analisa regresi untuk mengetahui hubungan nibah kelamin dan panjang ikan/The black dots showed the limit of interval class used for regression analysis to determine correlation between sex ratio and length distribution (120d"FLd"180).

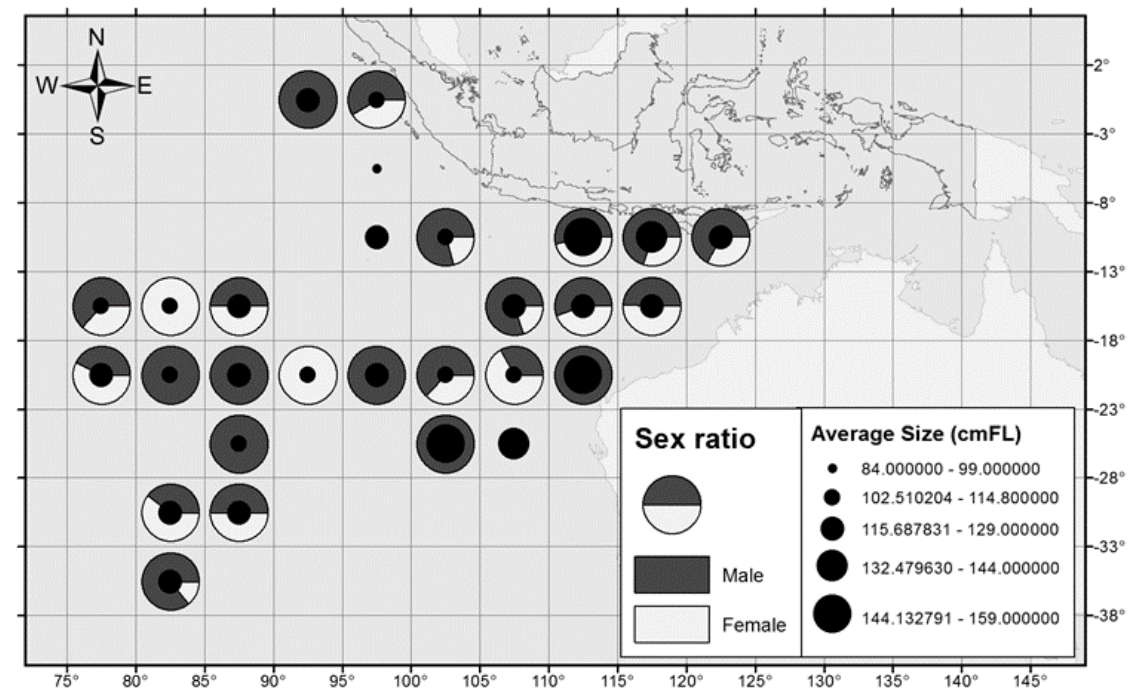

Gambar 6. Sebaran spasial nisbah kelamin ikan madidihang menurut ukuran panjang di Samudera Hindia bagian timur. Figure 6. Spatial distribution of sex ratio yellowfin tuna accordance with size in Eastern Indian Ocean. 


\section{Bahasan}

Lebih dari separuh madididang yang tertangkap memiliki ukuran yang lebih besar daripada ukuran matang gonad $\left(\mathrm{L}_{\mathrm{m}}\right)$ sehingga nilai rata-rata ukuran yang tertangkap $\left(\mathrm{L}_{\mathrm{c}}\right)$ pada penelitian ini lebih besar daripada $\mathrm{L}_{\mathrm{m}}$. Hal ini mengindikasikan bahwa sebagian besar madidihang yang tertangkap telah matang gonad dan berkesempatan untuk memijah. Besarnya ukuran hasil tangkapan madidihang pada penelitian ini dipengaruhi oleh jenis alat tangkap yang digunakan. Seluruh sampel madidihang ditangkap oleh rawai tuna yang merupakan alat tangkap pasif dan selektif (Barata et al., 2011; Nugraha \& Setyadji, 2013; Hutauruk, 2013). Rohit et al. (2012) melaporkan bahwa madidihang yang tertangkap rawai tuna di sepanjang pantai timur India memiliki ukuran panjang antara 20-185 cmFL dengan rata-rata $101,9 \mathrm{cmFL}$ dan tidak berbeda jauh dengan rata-rata pada penelitian ini $(101,65 \mathrm{cmFL})$. Nootmorn et al. (2005) juga melaporkan bahwa madidihang yang tertangkap oleh rawai tuna dan didaratkan di Phuket, Thailand memiliki ukuran panjang berkisar antara 95-157 cmFL. Muhammad \& Barata (2012) melaporkan ikan madidihang hasil tangkapan pancing ulur yang didaratkan di Kedonganan-Bali berukuran antara 81-170 cm. Sedangkan madidihang yang tertangkap oleh alat tangkap jaring seperti pukat cincin memiliki ukuran panjang dengan kisaran yang lebih kecil. Madidihang yang tertangkap pukat cincin di Teluk Tomini memiliki ukuran panjang cagak yang relatif kecil yaitu 10-80 cm (Mardlijah \& Rahmat, 2012).

Sebaran ukuran ikan selain dipengaruhi oleh jenis alat tangkap juga dipengaruhi oleh daerah penangkapannya. Ikan yang ditangkap pada perairan permukaan dengan bantuan alat pengumpul ikan atau rumpon ( $f i s h$ aggregating device) memiliki ukuran panjang cagak yang lebih kecil. Merta et al. (2006) melaporkan ikan madidihang yang tertangkap oleh aktivitas perikanan yang beroperasi di kolom permukaan perairan dan berasosiasi dengan rumpon didominasi oleh yuwana (juvenile) dengan persentase mencapai $98 \%$ dan modus ukuran panjang cagak antara 45-48 cm. Menurut Mardlijah \& Rahmat (2012), ikan madidihang yang tertangkap di sekitar rumpon di Teluk Tomini berukuran antara 11-190 cmFL dengan modus antara 30-40 cmFL. Ikan madidihang yang tertangkap rawai tuna memiliki ukuran lebih besar karena alat tangkap ini beroperasi pada kolom perairan yang lebih dalam untuk menjangkau swimming layer dengan sasaran ikan yang bergerombol bebas sehingga lebih banyak menggunakan taktik penangkapan berburu langsung di laut terbuka. Taktik penangkapan ini juga merupakan bentuk penyesuaian terhadap permintaan pasar yang menuntut ukuran ikan lebih besar sebagai bahan baku sashimi. Sedangkan tuna yang tertangkap di permukaan dengan menggunakan rumpon cenderung memiliki ukuran panjang yang lebih kecil sebagai bahan baku dalam industri pengalengan ikan (Nootmorn, et al., 2005).
Nisbah kelamin betina dan jantan berada pada kondisi yang tidak seimbang dimana jantan lebih dominan daripada betina. Hasil penelitian ini serupa dengan hasil penelitian sebelumnya oleh Rohit \& Rammohan (2009) yang melaporkan hasil tangkapan ikan madidihang di sekitar perairan Andhra (selatan India); Pradeep et al. (2014) di peraian Andaman dan Nicobar; Zhu et al. (2008) di Samudera Hindia bagian barat dan tengah; dan Marsac et al. (2006) yang melaporkan nisbah kelamin jantan lebih dominan daripada betina. Hasil pengamatan nisbah jenis kelamin pada penelitian ini berbeda dengan penelitian Zudaire et al. (2010) di Samudera Hindia bagian barat dan tengah yang melaporkan nisbah kelamin jantan dan betina adalah seimbang (1:1). Namun demikian, proporsi ikan madidihang jantan tetap mendominasi dengan tidak ditemukannya ikan madidihang betina pada ukuran panjang cagak diatas $155 \mathrm{~cm}$.

Nisbah kelamin jantan mendominasi pada ukuran panjang yang lebih besar, yaitu lebih dari $150 \mathrm{~cm}$, bahkan tidak ditemukan nisbah kelamin betina pada madidihang yang tertangkap dengan ukuran lebih dari $170 \mathrm{~cm}$. Menurut Marsac, et al., (2006), 65\% madidihang yang tertangkap di Samudera Hindia bagian barat pada ukuran $144 \mathrm{~cm}$ adalah jantan. Fonteneau (2002) melaporkan bahwa jantan mulai dominan dibandingkan betina pada ukuran $154 \mathrm{~cm}$. Dominasi madidihang jantan ini terjadi pada ukuran yang lebih besar dibandingkan dominasi jantan lainnya yang terjadi di Samudera Pasifik (134 cm) dan Atlantik $(146 \mathrm{~cm})$. Dominasi nisbah kelamin jantan pada ukuran panjang yang lebih besar juga ditemukan di tiga samudera di dunia (Capisano, 1991; Schaefer, 1998; Timochina, 1992 dalam Marsac, et al., 2006). Dominasi jantan pada ukuran besar ini diduga merupakan konsekuensi dari perbedaan laju pertumbuhan antara jantan dan betina dan atau dipengaruhi oleh perbedaan laju kematian alami dan kematian akibat penangkapan, dimana jumlah biomassa antara kedua jenis kelamin terakumulasi pada ukuran yang berbeda (Fonteneau, 2002; Marsac, et al., 2006).

Informasi tentang nisbah kelamin dapat digunakan untuk menduga kemampuan pemijahan suatu jenis ikan (Hamano \& Matsuura, 1987). Oleh karena itu, untuk memperoleh pemahaman yang lebih baik tentang aspek reproduksi dan pemijahan ikan madidihang, diperlukan informasi tentang pertumbuhan berbasis panjang ikan atau perkembangan harian/tahunan yang dapat diketahui melalui otolith dan tulang sirip. Selain itu, juga diperlukan data yang berkesinambungan (time series data) mengenai perkembangan tingkat kematangan gonad yang dapat diketahui melalui pendekatan histologi dan indeks kematangan gonad untuk memperoleh musim pemijahan ikan madidihang. Hal ini sangat penting dilakukan untuk menunjang pengelolaan perikanan sehingga dapat ditentukan ukuran dan waktu ikan saat memijah untuk mempertahankan kelestariannya di alam. 


\section{KESIMPULAN}

Distribusi ukuran panjang cagak ikan madidihang (Thunnus albacares) yang tertangkap rawai tuna di Samudera Hindia bagian timur berkisar antara 30-179 cm dimana sebanyak $81,03 \%$ telah layak tangkap dengan ukuran lebih besar dari ukuran pertama kali matang gonad $\left(\mathrm{L}_{\mathrm{m}}=100 \mathrm{~cm}\right)$. Nisbah kelamin madidihang yang tertangkap berada dalam kondisi tidak seimbang dengan perbandingan betina:jantan adalah 1:1,45. Jumlah ikan betina semakin berkurang bersamaan dengan pertambahan ukuran panjang cagaknya. Hubungan antara nisbah kelamin dan ukuran panjang dapat dideskripsikan dengan persamaan regresi yaitu nisbah kelamin betina $=1,8013$ $0,0099 \mathrm{FL} ; \mathrm{R}^{2}=0,8058$.

\section{PERSANTUNAN}

Tulisan ini merupakan kontribusi dari kegiatan program scientific observer pada kapal tuna longline di Samudera Hindia tahun 2005-2010 terselenggara atas kerjasama antara Pusat Penelitian Pengelolaan Perikanan dan Konservasi Sumberdaya Ikan dengan ACIAR-Australia melalui ACIAR PROJECT FIS/2002/074. Tulisan ini juga merupakan kontribusi kegiatan penelitian sumberdaya perikanan tuna di Samudera Hindia tahun 2011-2013 yang dibiayai oleh DIPA Balai Penelitian Perikanan Laut dan Loka Penelitian Perikanan Tuna.

\section{UCAPANTERIMAKASIH}

Penulis mengucapkan terima kasih kepada seluruh tenaga scientific observer di Loka Penelitian Perikanan Tuna yang telah membantu dalam proses pengumpulan data penelitian ini. Selain itu, penulis juga mengucapkan terima kasih kepada Drs. Bambang Sumiono, M.Si dan Dra. Sri Turni Hartati, M.Si atas saran dalam penyusunan makalah ini.

\section{DAFTAR PUSTAKA}

Andamari, R., J.H. Hutapea, \& B.I. Prisantoso. 2012. Aspek reproduksi ikan tuna sirip kuning (Thunnus albacares). Jurnal Ilmu dan Teknologi Kelautan Tropis 4 (1): 8996.

Anonimus. 1994. World review of highly migratory species and straddling stocks. FAO Fisheries Department. Technical Paper No. 337. FAO. Rome: 70 p.

Anonimus. 2012. Statistik Perikanan Tangkap Indonesia 2011. Direktorat Jenderal Perikanan Tangkap. Kementerian Kelautan dan Perikanan, Jakarta: 190 p.

Anonimus. 2013a. Report of the Sixteenth Session of the IOTC Scientific Committee. Indian Ocean Tuna
Commission. Busan, Republic of Korea 2-6 December 2013. IOTC-2013-SC16-R[E]: 312 pp.

Anonimus. 2013b. ISSF Tuna Stock Status Update, 2013(2): Status of the world fisheries for tuna. ISSF Technical Report 2013-04A. International Seafood Sustainability Foundation, Washington, DC, USA: 88 pp.

Barata,A., A.Bahtiar, \& H.Hartaty. 2011. Pengaruh perbedaan umpan dan waktu setting rawai tuna terhadap hasil tangkapan tuna di Samudera Hindia. Jur.Lit.Perik.Ind 17 (2): 133-138

Collete, H.B. \& C.E. Nauen. 1983. FAO Species Catalogue. Vol. 2. Scombrids of the world. An annonated and illustrated catalogue of tunas, mackerels, bonitos, and related species known to date. FAO Fisheries Synopsis. No. 125, Vol. 2. Rome, Italy: FAO Press: 137 pp.

Fonteneau, A. 2002. Estimated sex ratio of large yellowfin taken by purse seiners in theIndian Ocean: comparison with other oceans. IOTC Proceedings 5: 279-281

Fonteneau, A. 2005. An overview of yellowfin tuna stocks, fisheries and stock status worldwide. IOTC $7^{\text {th }}$ Working party on tropical tunas Phuket-Thailand, 18-22 July 2005:37 p.

Hamano, T. \& S. Matsuura. 1987. Sex ratio of the Japanese mantis shrimp in Hakata Bay. Nippon Suisan Gakkaishi, 53 (12): 22-79.

Hedianto, D.A \& S.E.Purnamaningtyas. 2013. Biologi reproduksi ikan golsom (Hemichromis elongatus, Guichenot1861) di Waduk Cirata, Jawa Barat. BAWAL Wid.Ris.Perik.Tangkap 5 (3): 159-166.

Hutauruk, R.M. 2013. Perhitungan stabilitas kapal perikanan melalui pendekatan ukuran utama dan koefisien bentuk kapal. J.Perik. dan Kel.18 (1): 4861.

Mardlijah, S. \& E. Rahmat. 2012. Penangkapan juvenile ikan madidihang (Thunnus albacares Bonnatere, 1788) di perairan Teluk Tomini. BAWAL Wid.Ris.Perik.Tangkap 4 (3): 169-176.

Marsac F, Potier M, Peignon C, Lucas V, Dewals P, Fonteneau A, Pianet R, \& Ménard F. 2006. Updated biological parameters for Indian Ocean yellowfin tuna and monitoring of forage fauna of the pelagic ecosystem, based on a routine sampling at the cannery in Seychelles. IOTC $8^{\text {th }}$ Working party on tropical tuna, Seychelles, 24-28 July 2006: 15 p. 
Merta, I.G.S., M. Nurhuda, \& A. Nasrullah. 2006. Perkembangan perikanan tuna di Pelabuhanratu. J.Lit.Perik.Ind. 12 (2): 117-127.

Muhammad, N. \& A. Barata. 2012. Stuktur ukuran ikan madidihang (Thunnus albacares) yang tertangkap pancing ulur di sekitar rumpon Samudera Hindia selatan Bali dan Lombok. BAWAL Wid.Ris.Perik.Tangkap 4 (3): 161-167.

Nootmorn, P., A. Yakoh, \& K. Kawises. 2005. Reproductive Biology of yellowfin tuna in the Eastern Indian Ocean. IOTC $7^{\text {th }}$ Working Party on Tropical Tuna, PhuketThailand 18-22 July 2005: 8 p.

Nugraha, B. \& B. Setyadji. 2013. Kebijakan pengelolaan hasil tangkapan sampingan tuna longline di Samudera Hindia. J.Kebijak.Perik.Ind 5 (2): 67-71

Pradeep.H.D, S.S.Shirke, S.K.Dwivedi, S.Ramachandran \& Premchand. 2014. Distribution, abundance and biology of yellowfin tuna, Thunnus albacares (Bonnaterre, 1788 ) in the Andaman and Nicobar waters. Journal of the Andaman Science Association 19 (2):191-200.

Rohit, P. \& K. Rammohan. 2009. Fishery and biological aspect of yellowfin tuna Thunnus albacares. Asian Fisheries Science 22: 235-244.
Rohit, P., G.S.Rao, \& K.Rammohan. 2012. Age, growth and population structure of the yellowfin tuna Thunnus albacares (Bonnaterre, 1788) exploited along the east coast of India. Indian Journal Fisheries 59 (1): 1-6.

Uktolseja J.C.B., B. Gafa \& S. Bahar. 1991. Potensi dan penyebaran sumberdaya ikan tuna dan cakalang dalam: Martosubroto P., N. Naamin, B.B.A. Malik, (editor). Potensi dan Penyebaran Sumberdaya Ikan Laut di Perairan Indonesia. Jakarta: Direktorat Jenderal Perikanan. Pusat Penelitian dan Pengembangan Perikanan. Pusat Penelitian dan Pengembangan Oseanologi. Jakarta.

Wudianto \& V.P.H. Nikijuluw. 2004. Guide to Invest on Fisheries in Indonesia. Directorate of Capital and Investment System. Ministry of Marine Affair and Fisheries Republic of Indonesia: 17p.

Zhu G, Xu L, Zhou Y, Song L. 2008. Reproductive biology of yellowfin tuna T.albacares in the west-central Indian Ocean. Journal of Ocean University of China (English Edition) 7: 327-332.

Zudaire, I., H. Murua, M. Grande, M. Korta, H. Arrizabalaga, J. Areso, \& D. Molina. 2010. Reproductive biology of yellowfin tuna (Thunnus albacares) in the western and central Indian Ocean. IOTC $12^{\text {th }}$ Working party on tropical tuna, VictoriaSeychelles, 18-25 October 2010: 25p. 